Fitzpatrick's own words, of getting "a hundred cents in service for each dollar of public funds expended, whatever the amount expended" (italics not the author's). After allowing for waste due to inefficiency and dishonesty, the amount expended is mainly a question of policy to be decided by the people through the proper legislative machinery. To confuse this fundamental problem of the extent of governmental functions with the problem of eliminating graft and waste is most unfortunate.

On the whole, it seems fair to say that Dr. Fitzpatrick's volume is too contentious to be of much help to the practical legislator confronted with the task of putting order and efficiency into the public housekeeping. On the other hand, it is too dogmatic and one-sided to be a safe guide to the student and general reader. In the hands of a skilful teacher or budget expert, however, it might be very useful in provoking discussion of the fundamental features of budget-making.

\section{C. Williamson.}

The Litrle Democracy: A Text-Book on Community Organization. By Ida Clyde Clarke, with introduction by $P$. P. Claxton, U. S. Commissioner of Education. New York: D., Appleton and Company, 1918. Pp. XV, 253.

Mrs. Clarke has brought together much of the best opinion and many fine prescriptions for community organization. Her book deals primarily with the school community center, but contains excellent chapters on the community garden, the community market, and the community kitchen. The chapters on various types of clubs are helpful.

Mrs. Clarke has drawn freely on the documents of various departments and bureaus at Washington and her volume is especially indebted to Dr. Henry E. Jackson of the bureau of education and Professor Hugh Findlay of the U. S. Department of Agriculture.

The volume cannot be pronounced an adequate treatise on community organization because it fails to raise or even suggest most of the difficulties of the subject, and there is lacking either a descriptive or analytical treatment of such decisive experiments as are being conducted in Cincinnati, in Framingham, in New York, under the leadership of Community councils, in New Haven, under the war bureau, in Kirksville, Mo., under the leadership of Mrs. Harvey. There is no reference to the growing contact between organized labor and the community movement, and the subjects of immigration and Americanization are left out.

But as far as its contents go, the book is interesting and practical.

\section{John Collier. \\ $*$}

OUr Neighborhood: Good Citizenship in Rural Communities. By John F. Smith, Professor of Social Science, Berea College Academy. Philadelphia and Chicago: The John C. Winston Company, 1918. Pp. XI, 262.

Professor Smith has written a text-book for country boys and girls, which approaches the ideal. It gives enough information for the boy or girl to know how to go about answering the questions at the end of each chapter, and these questions lead out into the entire problem of rural life. As an example of method, the book would have value for any urban teacher as well, and for any teacher of social science, even to graduate groups.

This text-book does more than give facts or arouse and direct intellectual interest. It is full of specific techniques, having to do with garnes, household arts, the protection of wild life, the reduction of waste on the farm. There are about seventy-five illustrations, all of which are well chosen and clearly printed.

This book can be unreservedly recommended. JoHn Collier.

Crime Prevention. By LieutenantColonel Arthur Woods. Princeton, N. J.: Princeton University Press. Pp. 124. $\$ 1$ net.

Although the title promises somewhat more than the contents warrant, the book 